\title{
Tetramicra brevifilum, a potential threat to farmed turbot Scophthalmus maximus
}

\author{
A. Figueras ${ }^{1}$, B. Novoa ${ }^{1}$, M. Santarém¹ ${ }^{1}$ E. Martínez ${ }^{2}$, J. M. Alvarez ${ }^{2}$, A. E. Toranzo ${ }^{3}$, \\ I. Dyková ${ }^{4}$ \\ ${ }^{1}$ Instituto Investigaciones Marinas CSIC, Eduardo Cabello 6, E-36208 Vigo, Spain \\ ${ }^{2}$ Piscicola del Morrazo, Nerga. Apdo. 141, Cangas, Pontevedra, Spain \\ ${ }^{3}$ Dpto. Microbiología y Parasitología, Facultad de Biología, Universidad de Santiago, Santiago de Compostela, E-19706 Spain \\ ${ }^{4}$ Institute of Parasitology, Branišovská 31, 3705 Česke Budějovice, Czechoslovakia
}

\begin{abstract}
The development of turbot Scophthalmus maximus culture has resulted in an increase of pathological problems involving mainly bacterial infections. During 1990, mortalities were detected in some grow-out facilities in Galicia, Spain, and were attributed to the microsporidian Tetramicra brevifilum Matthews \& Matthews, 1980. The outbreak lasted for 31/2 mo. The start of the outbreak was associated with a drop in temperature. Affected fish showed an erratic swimming behaviour, swelling of different parts of the body, darkening of the dorsal surface, and overproduction of mucus on the surface of the body. Fish with a high intensity of infection had jelly-like muscles. Small xenomas formed by $T$ brevifilum were found to be associated with regressive changes of the host tissue, with agglomerations of mature spores eliciting sometimes inflammatory reaction of the host. The agglutinin titers detected in naturally infected fish were low. There was a light host response. Electrophoresis of sera from naturally infected fish showed an additional protein band (molecular weight: $128 \mathrm{kDa}$ ) not found in uninfected samples. Results suggest that although turbot infected with microsporidians are immunologically impaired, the immunodepression does not increase the susceptibility of fish to vibriosis.
\end{abstract}

\section{INTRODUCTION}

In the past 5 yr there has been a considerable increase in turbot Scophthalmus maximus L. farming in Galicia (northwest Spain). The development of turbot culture has resulted in increasing pathological problems involving mainly bacterial infections (Toranzo et al. 1987, Toranzo \& Barja 1990, Toranzo et al. 1990, Fouz et al. 1991). On the other hand, pathological problems of viral, parasitic or neoplastic origin are not frequent (Devesa et al. 1989, Lupiani et al 1989, Lamas et al. 1990, Toranzo et al. 1990, Fernández-Puentes et al. 1991, Novoa et al. 1991).

During 1990, mortalities were detected in some grow-out facilities in Galicia which were attributed to microsporidian species. The size of affected juveniles as well as its prevalence was variable. The mortality of the fish was generally low, but the disease problem persisted for a long time (several months).

Microsporidia can produce important diseases in fish (Lom 1984) and have a worldwide distribution.
Heavy infections with Glugea stephani (Hagenmüller, 1889) and Microsporidium ovoideum (Thélohan, 1895) Sprague, 1977 have been reported in marine cultures of flounder Pleuronectes platessa L. (McVicar 1975, 1978, McVicar \& McKenzie 1977), and Microsporidium seriolae Egusa, 1982 (perhaps a species of Pleistophora) has caused severe mortalities in juveniles of Seriola quinqueradiata (see Lom 1984). Also, G. stephani suppresses the immune response of winter flounder Pseudopleuronectes americanus (Walbaum) (Laudan et al. 1987, 1989).

Matthews \& Matthews (1980) described a low prevalence of Tetramicra brevifilum in natural fish populations of turbot, off the north coast of Cornwall (UK). Until now there have been no reports on the prevalence of this parasite in farmed turbot. In this paper we report on mortality in stocks of cultured turbot infected with microsporidia in a grow-out plant located in Galicia. In addition to determination of the microsporidian agent, histopathology of infection and immune response of fishes to microsporidian infection were 
described. The possible increase in susceptibility of the diseased turbot to a secondary bacterial infection was assessed.

\section{MATERIAL AND METHODS}

Fish. Turbot with clinical signs of a diseased condition were selected from the stock reared in $4 \mathrm{~m}^{3}$ concrete tanks with a density $5 \mathrm{~kg}$ of fish per $\mathrm{m}^{3}$ and a continuous water flow of $2000 \mathrm{l} \mathrm{h}^{-1}$. The tanks were monitored twice a day. Temperature was taken during the peak of the mortality, All tanks containing the stock were affected.

Histopathology. Pieces of tissue, approximately $5 \mathrm{~mm}$ thick, of brain. gills, muscle, kidney, spleen and liver were excised, fixed in $10 \%$ buffered formalin, embedded in paraffin, sectioned at $5 \mu \mathrm{m}$, and staincd with homatoxylin and eosin. Ammodytes tobianus L., used as fresh food for turbot, was also examined.

Transmission electron microscopy (TEM). Small pieces of the liver parenchyma of infected turbot were fixed in $4 \%$ glutaraldehyde in $0.2 \mathrm{M}$ cacodylate buffer, stored in the same buffer for $3 \mathrm{mo}$, then postfixed in $1 \%$ cacodylate-buffered osmium tetroxide, dehydrated in ethanol and propylenoxide, and embedded in EponAraldite mixture. Thin sections were double stained with saturated aqueous uranium acetate and lead citrate, and examined in a Phillips 420 B electron microscope

Preparation of spores. Spores were collected from infected muscles and organs. Tissue samples containing xenomas or aggregates of mature spores were ground to release the spores. The suspension was filtered through $1 \mathrm{~mm}$ mesh screening, and then through tissue paper, followed by centrifugation at $3000 \times g$ for $10 \mathrm{~min}$. This procedure was repeated 3 or 4 times to obtain a spore pellet and remove extraneous material. The spores were then resuspended in phosphate buffered saline (PBS) and counted in a Neubauer chamber

Experimental infections. Two different experimental infections were conducted.

Expt 1: Two groups of 15 turbot (average weight $30 \mathrm{~g})$ were inoculated intraperitoneally with 2 doses of suspension containing $4.8 \times 10^{6}$ and $4.8 \times 10^{7}$ spores Another group of 15 fish were bathed in a suspension of $1.9 \times 10^{4}$ spores per ml for $7 \mathrm{~h}$. Fish were maintained at $15^{\circ} \mathrm{C}$ in 251 tanks using recirculated sea water with aeration. As controls for the intraperitoneal inoculation, fish were inoculated with PBS and subsequently treated as the infected fish. One week post-challenge onwards, samples of 2 fish were taken weekly for histology. At the same time, controls were collected for histological and microbiological analysis.
Expt 2: In order to evaluate whether the turbot infected with microsporidia had increased susceptibility to infection with other pathogens, infectivity trials were conducted using a virulent strain of Vibrio anguil larum (RV-22) isolated from turbot in our area (Toranzo et al. 1987). The virulence assays were performed as previously described (Toranzo et al. 1983). Briefly, 2 different groups of fish (naturally infected with microsporidia and healthy turbot) maintained in the conditions described above were challenged in parallel with bacterial doses ranging from $10^{2}$ to $10^{7}$ cells ( 6 fish per dose). Turbot injected with PBS were used as negative control

Mortalities were recorded daily over a 2 wk period Death of an experimental fish was considered to be caused by the inoculated bacteria if $R V-22$ vibrio strain was recovered in pure culture from the internal organs.

Agglutinin tests. Agglutinin tests were performed against microsporidian spores, using 2-fold dilutions of the turbot serum in 96-well plates. The amount of microsporidian spores used was $4.8 \times 10^{6} \mathrm{ml}^{-1}$. The mixtures were incubated overnight at room temperature. The titers were expressed as the reciprocal of the highest serum dilution in which agglutination was detected.

Leucocyte counts. One $\mathrm{ml}$ of blood was drawn from the heart of 18 fish with a heparinized syringe. Blood was diluted with PBS 1:10 v/v and then the leucocyte number was estimated in a Neubauer chamber. Student's t-test was used to compare the means of the 2 turbot groups (infected vs uninfected).

Serum electrophoresis. In order to compare the serum proteins profile from the infected and uninfected fish, serum samples from 10 spontaneously infected fish and 5 normal fish were subjected to SDS-PAGE (Laemmli 1970). Sera were mixed with sample buffer, boiled for 5 min and applied to $12 \%$ polyacrylamide mini-slab gels run for 30 min at $150 \mathrm{~V}$ The protein bands were visualized using the silver stain method described by Blum et al. (1987). Linear regression was applied to predict the molecular weight of the unknown proteins on the basis of mobility of known molecular weight standard proteins (Pharmacia)

\section{RESULTS}

\section{Time course of mortality}

The affected fish had been in the plant for 2 mo before the disease was detected. At first, the fish ceased feeding and soon afterwards started to die. Although the outbreak lasted for $3^{1 / 2} \mathrm{mo}$, the peak of mortality appeared on Day 49. Fish losses in the 
infected stock amounted to $11.5 \%$ (total stock $=30000$ fish).

During the epizootic the temperature fluctuated between 16.8 and $11.5^{\circ} \mathrm{C}$ but correlation between mortality and temperature variation was not detected. However, the start of the outbreak was associated with a drop in temperature (Fig. 1).

Growth of turbot infected with microsporidia was slow in comparison with several uninfected stocks monitored in the plant (Fig. 2). Growth rate in diseased fish was reduced by $50 \%$ in relation to that observed in uninfected stocks.

\section{Clinical and gross signs}

The affected fish showed erratic swimming behaviour. They also showed swelling of different parts of the body, darkening of the dorsal surface with white spots, and overproduction of mucus on the surface of the body. In fish with a high intensity of infection the muscle degenerated to give a viscous jelly-like aspect.

These fish had white nodules (1 $\mathrm{mm}$ in diameter), in the muscles, liver, kidney and spleen (Figs. 3 to 5).

In fish with a high intensity of infection the muscles were almost completely disintegrated having almost

Fig. 1. Scophthalmus maximus. Time-course of mortality of turbot infected with Tetramicra brevifilum. The decrease in temperature (arrow A) seems to be associated with an increase of mortality rate (arrow B)

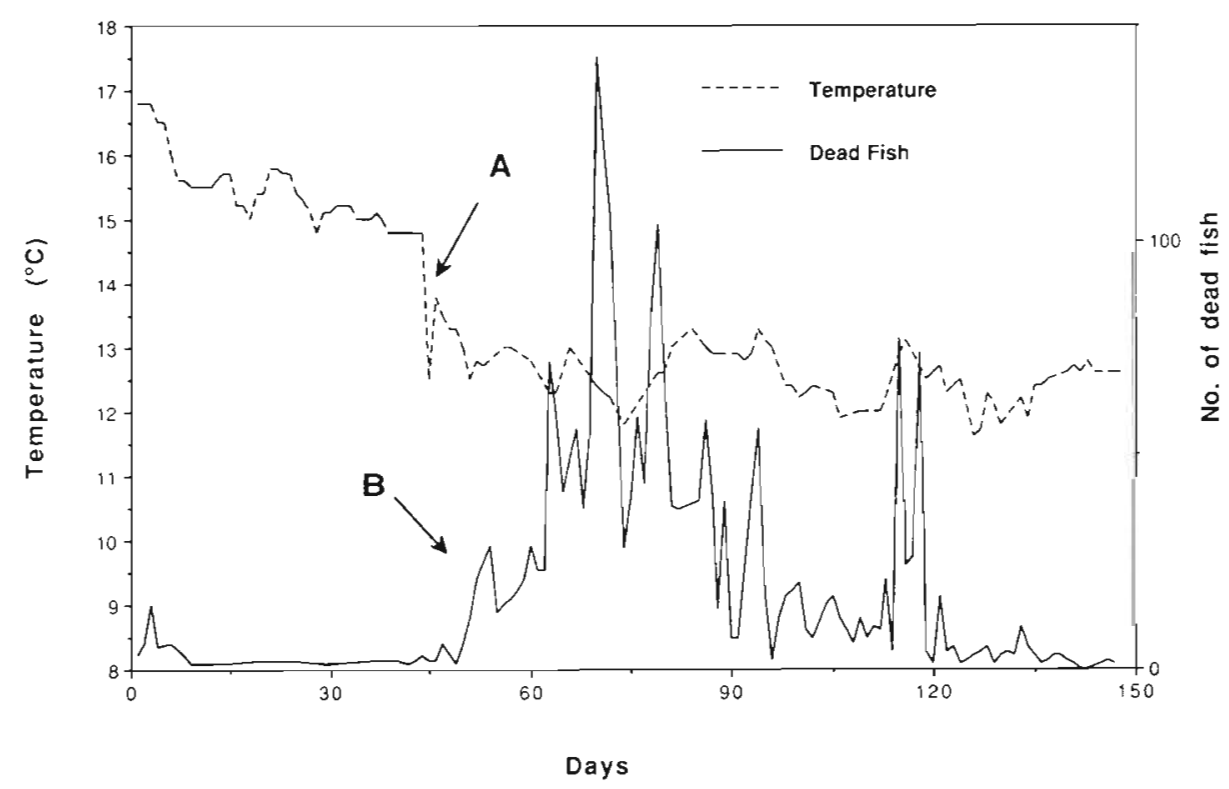

Fig. 2. Scophthalmus maximus. Weight growth curves of uninfected and infected stocks of the same age. The rectangle indicates the mortality period of the infected turbot

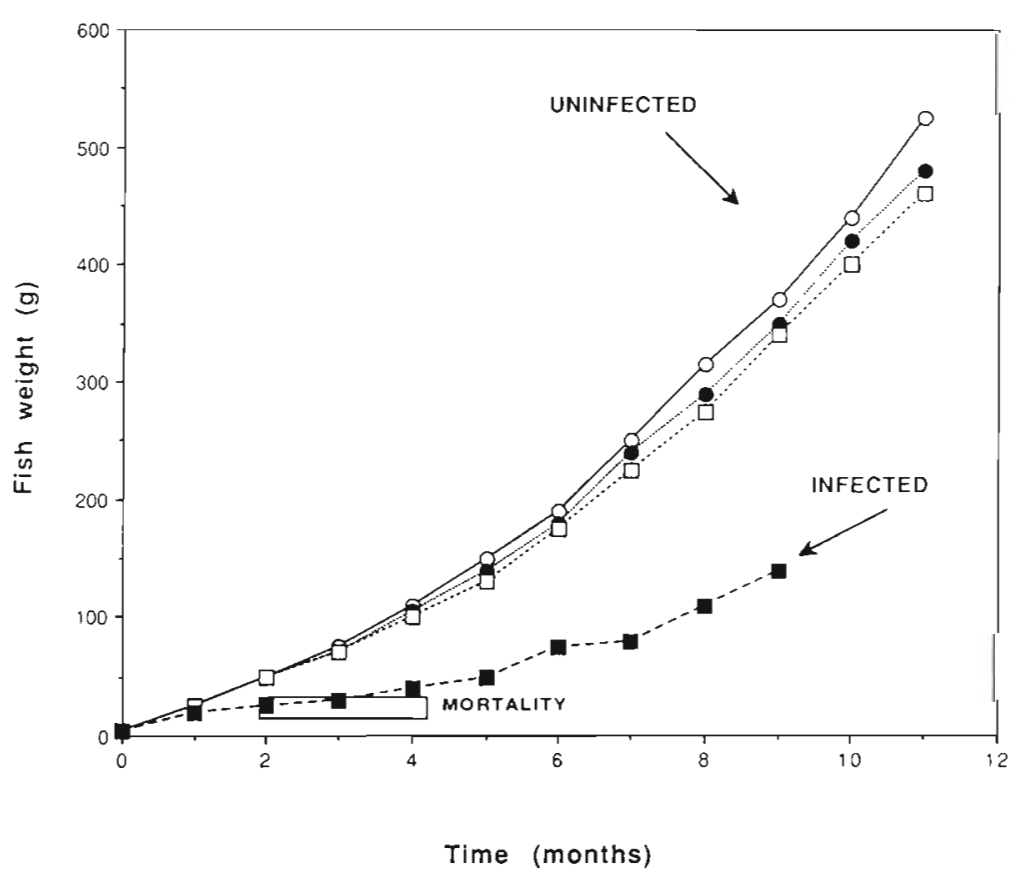



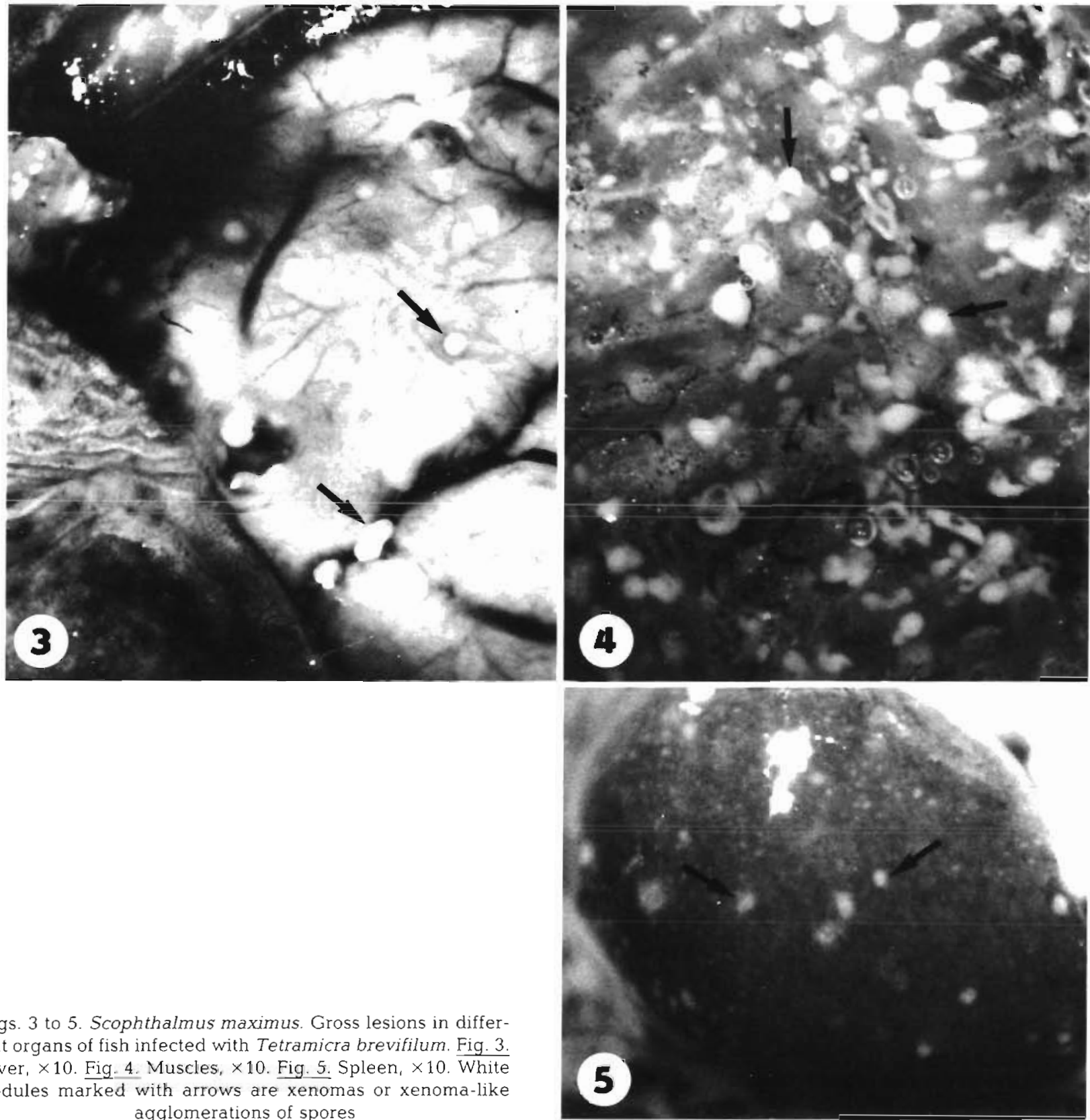

Figs. 3 to 5. Scophthalmus maximus. Gross lesions in different organs of fish infected with Tetramicra brevifilum. Fig. 3. Liver, $\times 10$. Fig. 4. Muscles, $\times 10$. Fig. 5. Spleen, $\times 10 . \overline{\text { White }}$ nodules marked with arrows are xenomas or xenoma-like agglomerations of spores

liquid consistency. No other pathogenic agent was found in the affected fish.

\section{Identity of microsporidian}

The elongate ovoid spores, in the fresh state, measured $4.8 \times 2 \mu \mathrm{m}$ (Fig. 6). A large inclusion was observed in the posterior vacuole. TEM revealed that the parasite induced xenoma formation (see Fig. 11). The xenoma surface was raised in tube-like villosities
(Fig. 7, inset), appearing reticulate in tangential section (Fig. 7). Merogony stages grew into cylindrical plasmodia with 3 to 8 nuclei within membrane-bound vacuole in xenoma cytoplasm (Fig. 7). No diplokarya were observed. Sporont stages produced sporoblasts by tetrasporoblastic fission (Fig. 9). Large electron-clense bodies were observed within the sporoblasts (Fig. 8). Mature spores contained 4 to 5 coils of the polar tube.

All these features are typical of Tetramicra brevifilum as described by Matthews \& Matthews (1980). A novel feature was the presence of a large amount of poly- 


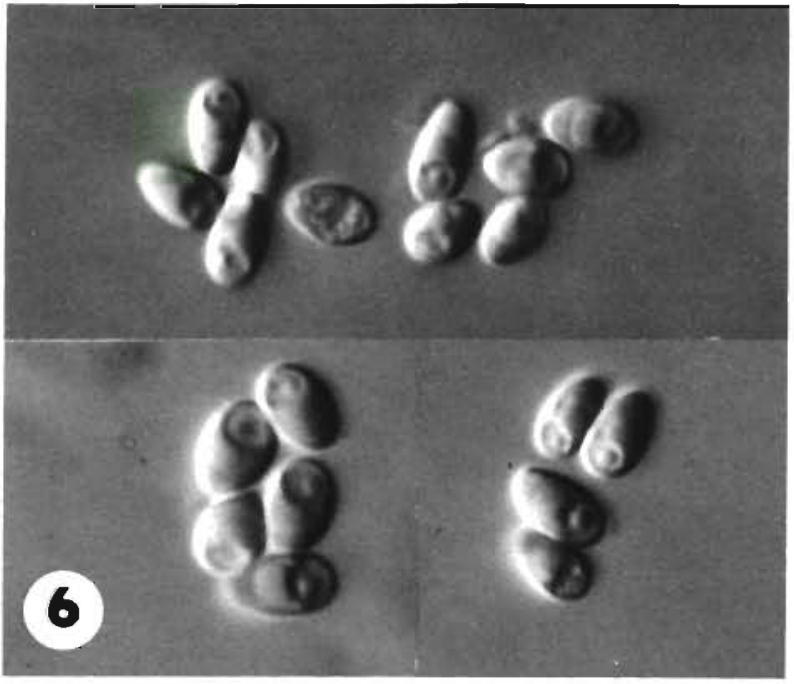

Fig. 6. Fresh spores of Tetramicra brevifilum in Nomarski differential interference contrast, $\times 2000$

ribosomes arranged into a regular paracrystalline pattern around the polar tube in the sporoblast (Fig. 10).

\section{Histopathological findings}

Xenomas and xenoma-like agglomerations of spores (Figs. 11 to 14) were detected in the liver, kidney, spleen, and gills. Except for pressure atrophy which was of considerable extent due to final size of xenomas (Fig. 11), advanced proliferative inflammation elicited around large agglomerations of spores was observed.

There was no difference in the intensity and prevalence of infection among the different organs examined.

Microsporidian infection was not found in the Ammodytes tobianus which were used as fresh food for turbot.

\section{Experimental infections}

Expt 1: Attempts of transmitting the disease did not result in any external or internal signs of infection $40 \mathrm{~d}$ post-injection. Xenomas were not detected in the histological sections of the tissues examined. No differences were found between the different ways of infection employed (intraperitoneal inoculation and immersion).

Expt 2: In the pathogenicity tests with Vibrio anguillarum, the $\mathrm{LD}_{50}$ values of the turbot infected with microsporidia vs healthy turbot were similar $\left(5 \times 10^{5}\right.$ and $6 \times 10^{5}$, respectively). In addition, no significant difference was observed in the evolution of the mortalities in both groups.

\section{Agglutinin titers and leucocyte numbers}

The agglutinin titers against microsporidian spores of the control (uninfected) fish were zero. The titers of the infected fish were low and highly variable $(\bar{x}=80$; $\mathrm{SD}=130$ )

The number of leucocytes in the infected fish was low $\left(\bar{x}=7.8 \times 10^{7} \mathrm{ml}^{-1} ; \mathrm{SD}=4.3 \times 10^{7}, \mathrm{n}=20\right)$ compared with uninfected fish $\left(\bar{x}=11 \times 10^{7} \mathrm{ml}^{-1}\right.$; $\left.\mathrm{SD}=3.3 \times 10^{7}, \mathrm{n}=20\right)$. The difference was statistically significant ( $t$-test, $p<0.05$ ).

\section{Serum electrophoresis}

All serum samples had similar protein profiles. However, naturally infected fish showed an additional protein band not found in the uninfected samples. The molecular weight of this protein was approximately $128 \mathrm{kDa}$ when compared to standards of known molecular weight.

\section{DISCUSSION}

Until 1990 microsporidiosis had not been detected in cultured turbot. The present description is the first record of an epizootic of Tetramicra brevifilum in a turbot farm in northwest Spain. Prior to the present record this microsporidian was only detected infecting wild turbot (Matthews \& Matthews 1980).

Nosemoides syaciumi Faye, 1992, described from the flatfish Syacium micrurum (Family Bothidae), has the same electron-dense body in the vacuole and the same number of coils of the polar tube, but the architecture of the spore differs as does the type of sporogenesis (polysporoblastic in N. syaciumi).

The presence of polyribosomes in the immature tubes, if confirmed in other populations of Tetramicra brevifilum, can be used as an additional differential feature. Polyribosomal structures were found in many other species (e.g. Heterosporis finki Schubert, 1969); however they were not associated with the polar tube.

In our study the infection was not present in all tanks but there was an overall mortality of $11.5 \%$. In other affected farms high mortalities have not been reported (pers. comms.). However we agree with Matthews \& Matthews (1980) that Tetramicra brevifilum should be considered a significant pathogen of turbot and a threat to aquaculture of this species since, in Spain: (1) the infection caused high fish losses, (2) the survivors of the outbreak had a low growth rate, and (3) turbot with a high intensity of infection showed liquefaction of the skeletal muscles, which made the fish unmarketable. Similar muscle liquefaction has been associated with other microsporidian infections (Reichenbach-Klinke \& 


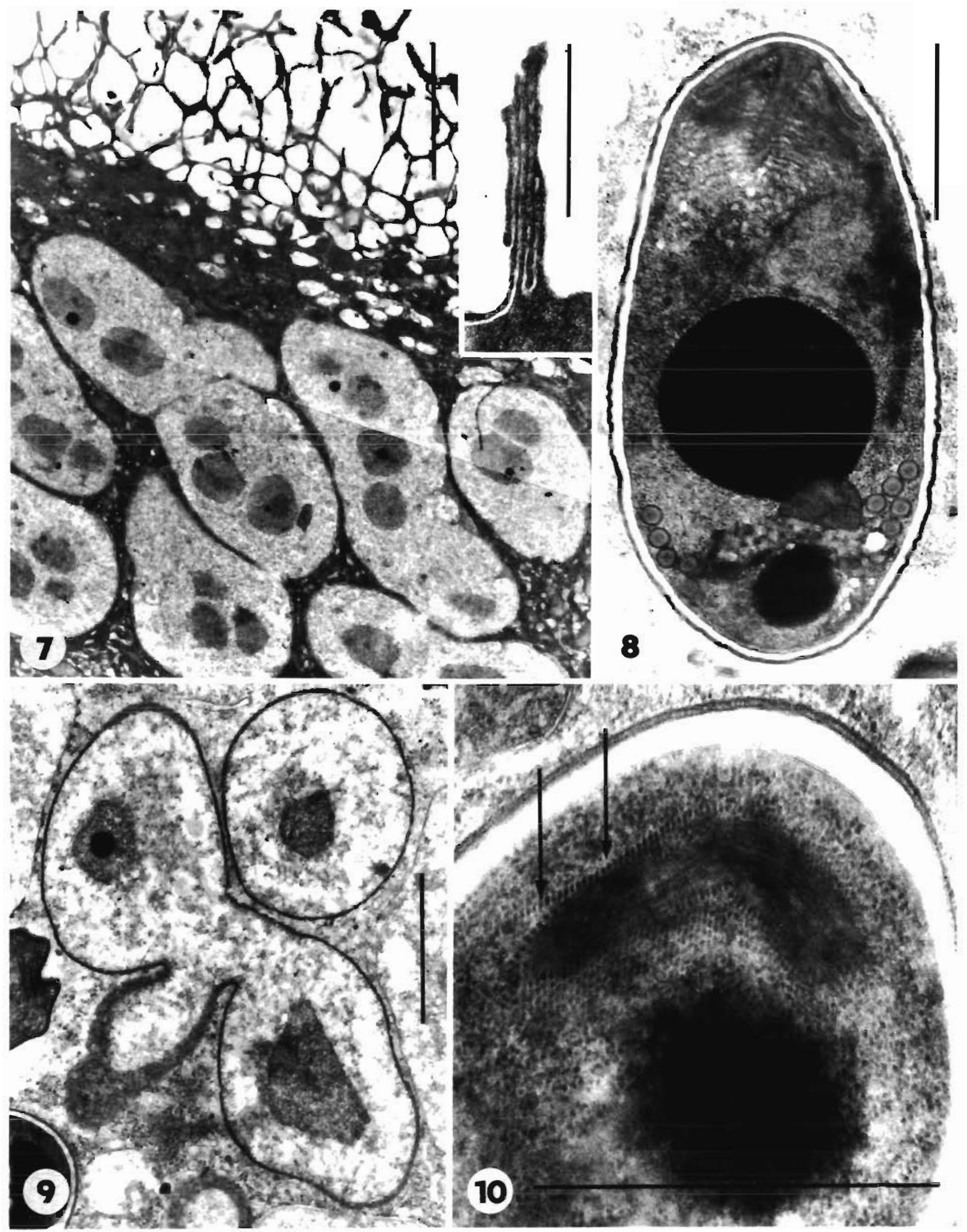


Figs. 7 to 10. Tetramicra brevifilum. Fig. 7. Periphery of xenoma in a tangential section showing reticulate appearance of surface villosities. Bar $=5 \mu \mathrm{m}$. Note the tube-like appearance of villosities in the inset. Bar $=1 \mu \mathrm{m}$. Fig. 8. Sporoblast with large electrondense bodies, 5 coils of the polar tube and an adhesive anchoring disc. Bar $=1 \mu \mathrm{m}$. Fig. 9 . Tetrasporoblastic cleavage of the sporont. Bar $=2 \mu \mathrm{m}$. Fig. 10. Polyribosomes arranged into a paracrystalline pattern around the polar tube in the sporoblast. Bar $=1 \mu \mathrm{m}$
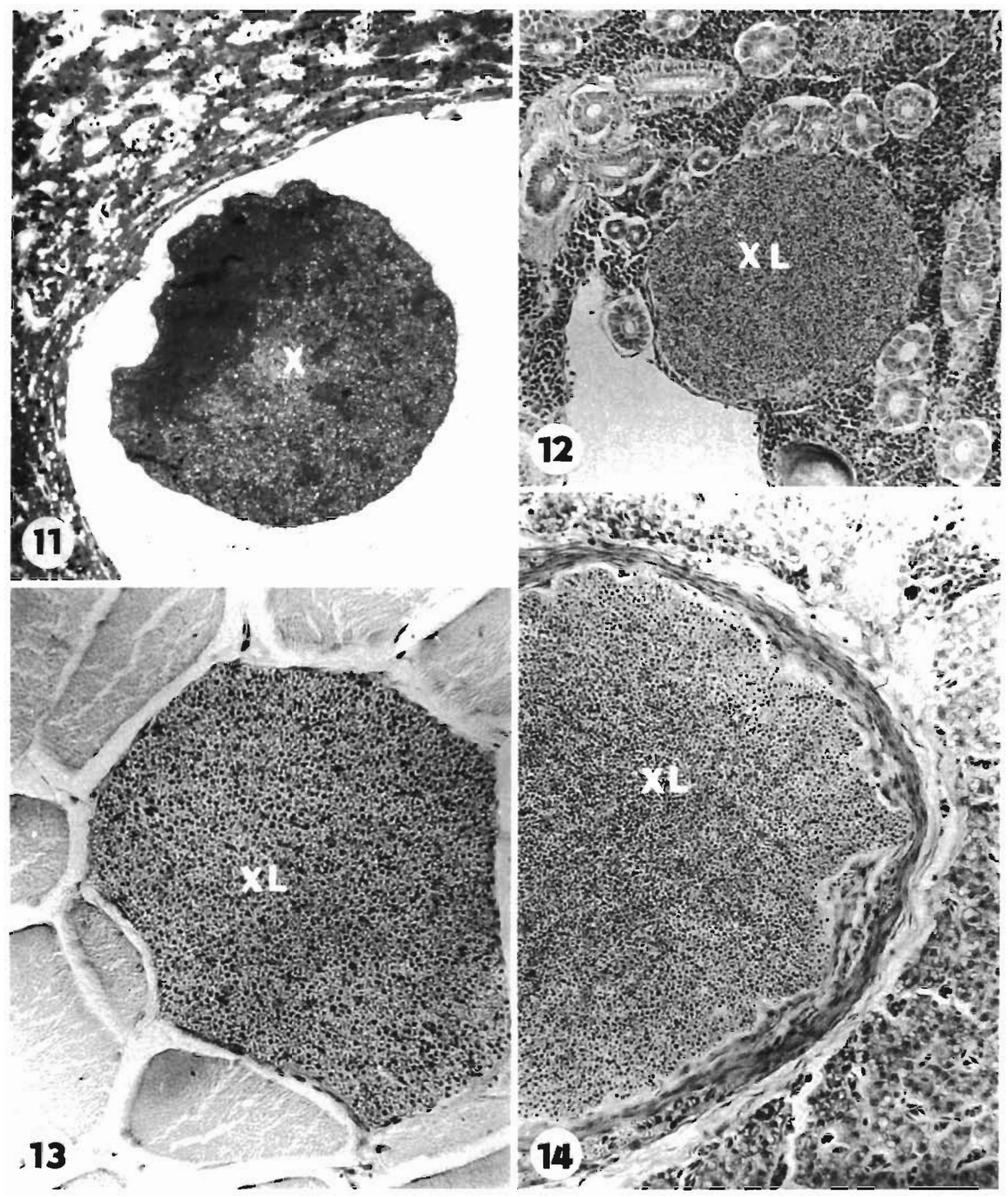

Figs. 11 to 14. Tetramicra brevifilum in various organs of turbot Scophthalmus maximus. Fig. 11. Xenoma (X) within an empty space in the liver parenchyma. Semithin section, toluidine blue, $\times 300$. Figs. 12 to 14 . Xenoma-like aggregates of spores (XL). Fig. 12. Aggregates of spores in interstitial tissue of kidney, $\times 400$. Fig. 13. Agglomeration of spores in subcutaneous muscle tissue, $\times 200$. Fig. 14 . Aggregate of spores in the liver parenchyma surrounded by host inflammatory reaction, $\times 400$ 
Elkan 1965, Canning 1967, Pulsford \& Matthews 1991) and myxosporidian infections (Konagaya 1980, Miller \& Spinelli 1982, Patashnik et al. 1982). Substances secreted by the parasite are thought to be responsible for the changes in the muscle cells (Dykova \& Lom 1980). Matthews \& Matthews (1980) found xenomas only in the connective tissues of the body musculature, but in the present investigation xenomas were found in all internal organs.

The origin of infection remains conjectural. The turbot were fed with Ammodytes tobianus throughout the epizootic but we could demonstrate the presence of any species of microsporidia in the food. A feasible explanation is that initial infection of the turbot occurred by ingestion of spores carried by other organisms present in the tanks such as copepods, decapod larvae and mysids. It has been suggested that small crustaceans may act as transport hosts for microsporidian spores (Stunkard \& Lux 1965, Overstreet 1973). After initiation of infection, in situ germination of spores may spread the infection throughout the tissues as suggested by Pulsford \& Matthews (1991).

In contrast with microsporidia in winter flounder (Cali et al. 1986), the disease in turbot was associated with a drop in temperature. In most of the cases described previously, the appearance of infections was concomitant with a rise in temperature. In the case of turbot, the growth of the parasites may have been accelerated by depression of the immune system when the temperature decreased.

The band with a molecular weight of approximately $128 \mathrm{kDa}$ that appeared in the serum of turbot infected with Tetramicra brevifilum is similar to that $(113 \mathrm{kDa})$ described by Laudan et al. (1989) in winter flounder infected with Glugea stephani. These authors concluded that further study is needed to determine whether this serum factor is indeed an immunomodulator, or simply a by-product of the parasite, or a product of parasite degradation.

The agglutinin titers detected in the fish naturally infected with Tetramicra brevifilum were low. These low values support the work of Laudan et al. (1987) in which immunosuppression was detected in serum of winter flounder infected with Glugea stephani. A possible explanation for the decrease of serum antibody in the infected turbot is that soluble serum factors secreted by the parasite may affecting the $T$ and $B$ cells directly. The existence of such substances is documented in parasites such as Trypanosoma cruzii (Imperio-Lima et al. 1985) and Leishmania donovani (Sacks et al. 1982). Another possibility is that the decline in the amount of serum antibodies occurs at the macrophage level with the release of mediators such as prostaglandins (Laudan et al. 1987, 1989)

Immunosuppression could explain the decrease in the circulating cells found in infected fish. However, it must be remembered that lymphopenia is not a specific sign associated with parasitism, since it has also been observed in stressed fish (Ellsaesser \& Clem 1986)

Our results indicate that, although turbot infected with microsporidia are immunologically impaired, the immunodepression does not increase the susceptibility of the fish to vibriosis. However, as the trial was limited to Vibrio anguillarum, we cannot rule out the possibility that the affected fish may be more predisposed to infection by other bacterial or viral pathogens, or may succumb more easily to environmental stress.

None of the different treatments tried (formalin, malachite green) was effective. The only way to eliminate the disease was careful management and removal of severely affected fish. In that way, the infective pressure may have been lowered and the intensity of reinfection of the remaining fish decreased. Although fumagilline DCH. which was recommended by Hedrick et al. (1991) as a treatment for microsporidiosis in salmon, was not tested, attempts to control the disease with this drug in another farm failed (pers. comm.).

Matthews \& Matthews (1980) accomplished the transmission of the disease by intramuscular injection, whereas their attempts to infect fish by feeding failed. In the present study, Tetramicra brevifilum infection was transmitted neither by intraperitoneal injection nor by immersion in sea water containing spores. New attempts to transmit the infection are being made using different doses and sites of injection.

Acknowledgements. We thank 'Piscicola del Morrazo S.L.' for providing the fish used in this study. We also thank J. R. Caldas for his technical assistance with histological procedures. This work was supported by the Grant MAR91-1133C02-02 from the Comision Interministerial de Ciencia y Tecnología (CICYT) Spain. B. Novoa acknowledges the Ministerio de Educación y Ciencia (Spain), and Maria Santarém the Junta Nacional de Investigaçio Científica e Tecnológica (Portugal), for research fellowships.

\section{LITERATURE CITED}

Blum, H., Beier, H., Gross, H. J. (1987). Improved silver staining of plant proteins, RNA and DNA in polyacrylamide gels. Electrophoresis 8: 93-99

Cali, A., Takvorian, P. M., Ziskawski, J. J., Sawyer, T K. (1986). Experimental infection of american winter flounder with Glugea stephani. J. Fish Biol. 28(2): 199-206

Canning, E. U. (1967). Vertebrates as host to microsporidia with special reference to rats infected with Nosema cuniculi. Protozoology (Supplement, J. Helminthol.) 2: 197-205

Devesa, S., Barja, J. L., Toranzo, A. E. (1989). Ulcerative fin and skin lesions in reared turbot (Scophthalmus maximus L.). J. Fish Dis. 12: 323-333

Dyková, I., Lom. J. (1980). Tissue reactions to microsporidian infections in fish. J. Fish Dis. 3: 265-283 
Ellsaesser, C. F., Clem, L. W. (1986). Haematological and immunological changes in channel catfish stressed by handling and transport. J. Fish Biol. 28: 511-521

Fernández-Puentes, C., Novoa, B., Núnez, S., Figueras, A. J., Toranzo, A. E. (1991). The turbot diseases in a Galician farm (Spain): one year study. European Aquaculture Society, Spec. Publ. 14: 97-98

Fouz, B., Larsen, J. L., Toranzo, A. E. (1991). Vibrio damsela as a pathogenic agent causing mortalities in cultured turbot (Scophthalmus maximus L.). Bull. Eur Ass. Fish Path. 11: 80-81

Hedrick, R. P., Groff, J. M., Baxa, D. V (1991). Experimental infections with Enterocytozoon salmonis Chilmonczyk, Cox, Hedrick (Microsporea): an intranuclear microsporidium from chinook salmon Oncorhynchus tshawytscha. Dis. aquat. Org. 10: 103-108

Imperio-Lima, M. R., Joskowicz, M., Coutinho, A., Kipnish, H. L., Eisen, H. (1985). Very large and isotypically and atypically polyclonal PFC response in mice infected with Trypanosoma cruzij. Eur. J. Immunol. 15: 201-203

Konagaya, S. (1980). Jellification and protease activity of yellowfin sole muscle in association with a myxosporidian parasite. Bull. Jap. Soc. Scient. Fish. 46: 1019-1026

Laemmli, U. K. (1970). Cleavage of structural proteins during the assembly of the head of bacteriophage T4. Nature 227 : $680-685$

Lamas, J., Anadón, R., Devesa, S., Toranzo, A. E. (1990). Visceral tumors and epidermal papillomas in cultured turbot (Scophthalmus maximus L.). Dis. aquat. Org. 8: $179-187$

Laudan, R., Stolen, J. S., Cali, A. (1987). The immunomodulating effect of the microsporidan Glugea stephani on the humoral response and immunoglobulin levels in winter flounder, Pseudopleureonectes americanus. J. Fish Biol. 31 (suppl. A) : 155-160

Laudan, R., Stolen, J. S., Cali, A. (1989). The effect of the microsporida Glugea stephani on the immunoglobulin levels of juvenile and adult winter flounder (Pseudopleureonectes americanus). Devl comp. Immunol. 13. $35-41$

Lom, J. (1984). Diseases caused by protistans. In: Kinne, O. (ed.) Diseases of marine animals, Vol. IV. Part 1. Biologische Anstalt Helgoland, Hamburg, p. 114-168

Lupiani, B., Dopazo, C. P., Ledo, A., Fouz, B., Barja, J. L., Hetrick, F. M., Toranzo, A. E. (1989). A new syndrome of mixed bacterial and viral etiology in cultured turbot (Scophthalmus maximus L.). J. aquat. Anim. Health 1: 197-204

McVicar, A. H. (1975). Infection of plaice Pleuronectes platessa with Glugea stephani (Hagenmuller 1899) (Protozoa: Microsporidia) in a fish farm and under experimental conditions. J. Fish Biol. 7.611-619

Responsible Subject Editor: W. Körting, Hannover, Germany
McVicar, A. H. (1978). Flatfish at risk; trials pinpoint danger from disease. Fish Farmer 2(1): 32-33

McVicar, A. H., McKenzie, K. (1977). Effects of differents systems of monoculture on marine fish parasites. In: Cherret, J. M., Sagar, G. R. (eds.) Origins of pest, disease and weed problems. Blackwell, Oxford, p. 163-182

Matthews, R. A., Matthews, B. F. (1980). Cell and tissue reaction of turbot Scophthalmus maximus $\mathrm{L}$. to Tetramicra brevifilum (Microspora). J. Fish Dis. 3: 495-515

Miller, R., Spinelli, J. (1982). The effect of protease inhibitors on proteolysis in parasitised Pacific whiting, Merluccius productus, muscle. Fish. Bull. U.S. 80: 281-2876

Novoa, B., Figueras, A. J., Ledo, A., Barja, J. L., Toranzo, A. E. (1991). Incidence of Birnavirus in cultured turbot (Scophthalmus maximus L.) in Northwest Spain. Fish Health Section/American Fisheries Society Newsletter 19(2): 2-3

Overstreet, R. M. (1973). Parasites of some penaeid shrimps with emphasis on reared hosts. Aquaculture 2: 105-140

Patashnik, M., Groninger, H. S., Barnett, H., Kudo, G., Koury, B. (1982). Pacific whiting Merluccius productus: 1. Abnormal muscle texture caused by myxosporidian induced proteolysis. Mar. Fish. Rev. 44: 1-12

Pulsford, A., Matthews, R. A. (1991). Macrophages and giant cells associated with a microsporidian parasite causing liquefaction of the skeletal muscle of the Norway pout. Trisopterus esmarkii (Nilsson). J. Fish Dis. 14: 67-78

Reichenbach-Klinke, H., Elkan, E. (1965). The principal diseases of lower vertebrates. Academic Press, New York

Sacks, D. L., Bancroft, G., Evans, W. H., Askonas, B. A. (1982). Incubation of trypanosome-derived mitogenic and immunosuppressive products with peritoneal macrophages allows recovery of biological activities from soluble parasite fractions. Infect. Immun. 36: 160-168

Stunkard, H. W., Lux, F. E. (1965). A microsporidian infection of the digestive tract of the winter flounder, Pseudopleuronectes americanus. Biol. Bull. 129: 371-387

Toranzo, A. E., Barja, J. L. (1990). A review of the taxonomy and seroepizootiology of Vibrio anguillarum with special reference to aquaculture in the northwest of Spain. Dis. aquat. Org. 9: 73-82

Toranzo, A. E., Barja, J. L., Potter, S. A., Colwell, R. R., Hetrick, F. M., Crosa, J. H. (1983). Molecular factors associated with virulence of marine vibrios isolated from striped bass in Chesapeake Bay. Infect. Immun. 39: 1220-1227

Toranzo, A. E., Santos, Y., Lemos, M. L., Ledo, A., Bolinches, J (1987). Homology of Vibrio anguillarum strains causing epizootics on turbot, salmon and trout reared in the Atlantic coast of Spain. Aquaculture 67: 41-52

Toranzo, A. E., Santos, Y., Bandin, I., Romalde, J. L., Ledo, A. Barja, J. L. (1990). Five year survey of bacterial fish infections in continental and marine aquaculture in northwest of Spain. World Aquaculture 21.91-94

Manuscript first received: March 12, 1992

Revised version accepted: July 6, 1992 